\title{
Anti-leishmanial effects of resveratrol and resveratrol nanoemulsion on Leishmania major
}

\author{
Parisa Mousavi ${ }^{1}$, Bahman Rahimi Esboei ${ }^{2 *}$, Maryam Pourhajibagher ${ }^{3 *}$, Mahdi Fakhar ${ }^{4}, Z^{2}$ abihollah Shahmoradi ${ }^{1}$, \\ Seyed Hossein Hejazi ${ }^{5}$, Hadi Hassannia ${ }^{6}$, Ayatollah Nasrollahi Omran ${ }^{2}$ and Hamid Hasanpour ${ }^{7}$
}

\begin{abstract}
Background: Leishmaniasis is a vector-borne disease that is endemic in the tropical and sub-tropical areas of the world. Low efficacy and high cytotoxicity of the current treatment regimens for leishmaniasis is one of the most important health problems. In this experimental study, anti-leishmanial effects of different concentrations of resveratrol and resveratrol nano-emulsion (RNE) were assessed.
\end{abstract}

Methods: RNE was prepared using the probe ultra-sonication method. The cytotoxicity was evaluated using the MTT technique on the L929 cell line. The anti-leishmanial activities on promastigotes of leishmania were assessed using vital staining and infected BALB/c mice were used to assess the in vivo anti-leishmanial effects.

Results: In vitro and in vivo assays revealed that all concentrations of resveratrol and RNE had valuable inhibitory effects against Leishmania major in comparison to the control group $(P<0.05)$. The half maximal inhibitory concentration $\left(I C_{50}\right)$ values were calculated as 16.23 and $35.71 \mu \mathrm{g} / \mathrm{mL}$ for resveratrol and RNE, respectively. Resveratrol and RNE showed no cytotoxicity against the L929 cell line.

Conclusions: According to the potent in vitro and in vivo anti-leishmanial activity of RNE at low concentration against $L$. major, we suggest that it could be a promising anti-leishmanial therapeutic against $L$. major in the future.

Keywords: Anti-leishmanial activity, Leishmania major, Resveratrol, Resveratrol nanoemulsion

\section{Introduction}

Leishmaniasis is a tropical disease caused by a vector borne protozoan parasite of the genus Leishmania that is an endemic disease in 102 countries in five continents with 12 and 15 million infected cases in the world, 350 million are at risk, 1.5 to 2 million new cases and 70,000 deaths annually $[1,2]$. The disease has a spectrum of

\footnotetext{
*Correspondence: Bahman5164@yahoo.com; m-pourhajibagher@alumnus. tums.ac.ir

${ }^{2}$ Department of Parasitology and Mycology, School of Medicine, Tonekabon Branch, Islamic Azad University, Tonekabon, Iran

${ }^{3}$ Dental Research Center, Dentistry Research Institute, Tehran University

of Medical Sciences, Tehran, Iran

Full list of author information is available at the end of the article
}

clinical manifestations from self-healing skin ulcers to serious visceral manifestations. The cutaneous leishmaniasis $(\mathrm{CL})$ is typically localized to the skin and infects dermal macrophages and in the more advanced stages; metastasis to the mucosal tissue and bone marrow maybe occur [2]. Iran is one of the most important endemic countries in the Middle East and all clinical forms of CL have been reported during the last decades [3-5]. CL, the most prevalent form, is caused by $L$. major and L. tropica in the old world, and more than 39 million people are at risk [6]. Chemotherapy is essential for leishmaniasis control and treatment. The development of drug resistance and the emergence of new strains of the parasite are the important factors that restricted the prevention and 
control programs and moreover, no effective vaccine has been developed yet [7]. Pentavalent antimonials, such as meglumine antimoniate (glucantime) and sodium stibogluconate (pentostam), are used as the first therapeutic line for CL [8] but due to high toxicity, high cost, longterm treatment course, drug resistance, relapse, and not significant effectiveness; new drug discovery is essential [9]. Hence, World Health Organization (WHO) recommends the use of medicinal plants and natural compounds as complementary or alternative therapies. Due to the various useful drugs derived from medicinal plants and natural compounds, access to new sources of drugs against leishmaniasis would be helpful [10-12].

Resveratrol (3,5,4' -trihydroxy-trans-stilbene) belongs to the polyphenols' stilbenoids group, having two phenolic rings linked to each other by an ethylene bridge. This natural polyphenol has been found in at least 72 plant species, especially in grapes' skin and seeds, and was detected in discrete amounts in red wines and various human foods $[13,14]$. Resveratrol has many biological properties including antioxidant, cardioprotective, neuroprotective, antimicrobial, anti-inflammatory, and anticancer activities [15]. In addition to the mentioned biological activities, it is a phytoalexin that acts to inhibit the growth of some pathogenic microorganisms, such as bacteria and fungi. The anti-leishmanial effectiveness of the resveratrol was assessed by Ferreira et al. and Kedzierski et al. against L. amazonensis and L. major strains, respectively in an in vitro situation with the half maximal inhibitory concentration $\left(\mathrm{IC}_{50}\right)$ of 27 and $65.5 \mu \mathrm{M}$, respectively [16, 17]. Resveratrol and related stilbenes in plants are contributed as an important mechanism in host defense against infection, injury, and wounding [18-20]. Nanomaterials (NMs) are advantageous as the active antimicrobial agents because of their exceedingly large relative surface to their size. Nanosized drugs even with a low dose are high active [21]. Therefore, NMs could serve as the alternative of current anti-infective agents to control microbial infections. The aim of this study was to assess in vitro and in vivo activities of resveratrol and RNE on growth and proliferation of $L$. major (Iranian strain MRHO/IR/75/ER) promastigotes and $\mathrm{BALB} / \mathrm{c}$ mice, respectively.

\section{Materials and methods}

\section{Chemicals supply}

Glacial acetic acid, Dimethyl sulfoxide (DMSO: 99\%), sodium chloride, Tween 80 , ethanol, and neutral red were purchased from Merck chemical company (Frankfort, Germany). Resveratrol, MTT (3-(4,5-dimethylthiazol2-yl)2,5- diphenyltetrazolium bromide) kit, Roswell Park Memorial Institute (RPMI)-1640 medium, Dulbecco's Modified Eagles Medium (DMEM), Griess reagent (1\% sulfanilamide in $\mathrm{H}_{3} \mathrm{PO}_{4}(10 \% \mathrm{v} / \mathrm{v})$ in Milli-Q water), heatinactivated fetal bovine serum (FBS), and the penicillinstreptomycin solution $(10,000 \mathrm{U} / \mathrm{mL})$ were purchased from Sigma-Aldrich (USA). Giemsa, hematoxylin, and eosin stains were obtained from Merck chemical company (Frankfort, Germany). Polyvinyl chloride (PVC) was purchased from Hatano Research Institute, Kanagawa, Japan. Amphotericin B was obtained from Abelcet, Liposome Company, Princeton, NJ (USA).

\section{Preparation and characterization of resveratrol nanoemulsion (RNE)}

The homogenization followed by the probe ultra-sonication method was performed for preparing the nanoparticles. First, to determine the best formulation based on the percentage of lipophilic and hydrophilic surfactants, $400 \mathrm{mg}$ of solid lipid with $100 \mathrm{mg}$ of resveratrol and $250 \mathrm{mg}$ span 80 or span 60 were melted at $85^{\circ} \mathrm{C}$. Then, the hot lipid phase was dispersed in the $1 / 3$ aqueous solution containing $500 \mathrm{mg}$ of hydrophilic surfactant (Tween 80), heated at the same temperature, homogenized by highshear homogenizer at 13,000 rpm for $7 \mathrm{~min}$ (D-91126 Schwabach, Heidolph, Germany), and then sonicated by a probe sonicator (Bandelinsonopuls, 3100, Berlin, Germany) at power levels of $3.5 \mathrm{~W}$ for $5 \mathrm{~min}$ to form a coarse pre-emulsion. The mixture was then dispersed into $2 / 3$ of an ice-cold surfactant solution preserved in an ice bath. The final mixture was sonicated again at power levels of $0.6 \mathrm{~W}$ for $10 \mathrm{~min}$ while dipped in the ice bath. This cooling phase encouraged the formation of lipid nanoparticles. The size, size distribution, zeta potential, and poly disparity index (PDI) of RNE were determined using a dynamic light scattering (DLS) technique with a Zetasizer Nano ZS (Malvern Instruments Ltd., UK) with a wavelength of $632.8 \mathrm{~nm}$ and scattering angle of $173^{\circ}$. Furthermore, the RNE size dispersion and morphology were confirmed by Transmission Electron Microscope (TEM) (Seron Technology, AIS2100, Iran).

\section{Preparation of L. major}

L. major promastigotes, Iranian strain MRHO/IR/75/ER, were provided by the department of parasitology, Tehran University of Medical Sciences, Tehran, Iran and were cultivated in RPMI-1640 medium supplemented with $10 \%$ FBS and penicillin-streptomycin solution at $24{ }^{\circ} \mathrm{C}$ with frequent passages every three days [22].

\section{In vitro assay}

The experiments were done separately for $12,24,48$, and $72 \mathrm{~h}$ in a 96-well microtiter plate. At first, $100 \mu \mathrm{L}$ RPMI-1640 medium containing $10^{5}$ promastigotes (at log phase) was added to each well. Then resveratrol and RNE were added separately to the wells in triplicate at 
concentrations of 50, 100, 200, and $400 \mu \mathrm{g} / \mathrm{mL}$. Amphotericin $\mathrm{B}(20 \mathrm{mg} / \mathrm{mL})$ as a positive control was considered in three wells, in a concentration of $12 \mu \mathrm{M}$. In another row, $100 \mu \mathrm{L}$ of medium containing parasites with phosphate buffered saline (PBS) without the drug was added as the negative controls. The plate was incubated at $24{ }^{\circ} \mathrm{C}$ for $12,24,48$, and $72 \mathrm{~h}$. At the end of incubation, live and dead promastigotes were counted after adding $0.1 \%$ eosin stain with a light microscope and the $\mathrm{IC}_{50}$ values were calculated by nonlinear least-squares regression analysis with Microsoft Excel 2010 [22, 23].

\section{Assessment of the parasite load in macrophage}

For the assessment of the parasite load, $2 \times 10^{5}$ of 5774 . A1 macrophages cells were cultured in a 24-well microtiter plate containing a $13 \mathrm{~mm}$-diameter coverslip per well, and supplemented RPMI medium supplemented with $10 \%$ FCS and $100 \mathrm{U} / \mathrm{ml}$ penicillin and $100 \mu \mathrm{g} / \mathrm{mL}$ streptomycin and incubated at $37{ }^{\circ} \mathrm{C}$ in $\mathrm{CO}_{2} 5 \%$ for $24 \mathrm{~h}$. Promastigotes of $L$. major at the stationary phase were seeded into each well (1:10) and incubated for $24 \mathrm{~h}$ and the non-internalized parasites were removed by aspirating the supernatant. The infected macrophages were then treated with the concentrations of 50,100, 200, and $400 \mu \mathrm{g} / \mathrm{mL}$ of resveratrol and RNE. The number of infected macrophages and the number of amastigotes per macrophage were determined by counting the number of parasites in 100 macrophages in a neubauer chamber.

\section{In vivo assay}

This study was performed in accordance with ARRIVE guidelines (https://arriveguidelines.org). Female BALB/c mice (6-7 weeks old) purchased from Razi Rad Industries were used for experimentation and kept in standard boxes under controlled light and temperature conditions. Overall, $1.6 \times 10^{6}$ promastigotes, in the stationary phase, were injected subcutaneously in the base of the tail of mice. The mice were divided into 10 groups and five mice were allocated in each group. Based on the efficacy assay in vitro, the treatment groups were as follows: groups one to five were treated with $5,10,15,20$, and $40 \mathrm{mg} / \mathrm{kg}$ body weight $(\mathrm{BW})$ of resveratrol and groups six to eight were treated with 5,10 , and $20 \mathrm{mg} / \mathrm{kg} \mathrm{BW}$ of RNE, respectively. Groups 9, 10, and 11 were treated with Amphotericin $B(1 \mathrm{mg} / \mathrm{kg} \mathrm{BW})$ as the positive control and PBS as the negative control groups, respectively. After three weeks, treatment was started when local lesions were apparent. To confirm the presence of Leishmania parasite, samples from each lesion were smeared and fixed with absolute methanol and stained with giemsa for detection of amastigotes by using the light microscope $(1000 \times)$. Topical treatment was used on each mouse every 28 continuous days. The diameter of lesions was measured weekly before and after treatment by dial micrometer (Starrett Dial indicator, model 25A, USA) and compared with that of untreated lesions. The ulcer size was determined according to the following formula (a: Length and b: width) [22]:

$$
\text { Lesionsize }=\frac{a+b}{2}
$$

\section{Indirectly measurement of nitric oxide (NO) production}

NO levels were evaluated using Griess reaction and compared to the untreated macrophages. In a 96-well microtiter plate, $2 \times 10^{5}$ murine peritoneal macrophages were cultured at $37{ }^{\circ} \mathrm{C}$ in $5 \% \mathrm{CO}_{2}$ for $4 \mathrm{~h}$ to allow cell adhesion. $100 \mu \mathrm{L}$ of new medium containing promastigotes in stationary phase (10 promastigotes per macrophage) was added. $100 \mu \mathrm{L}$ of the resveratrol and $\operatorname{RNE}(50,100$, 200 , and $400 \mu \mathrm{g} / \mathrm{mL}$ ) were added to the wells with $L$. major amastigote and then incubated at $37^{\circ} \mathrm{C}$ in $5 \% \mathrm{CO}_{2}$ for $24 \mathrm{~h}$. After the incubation times, the level of $\mathrm{NO}$ was analyzed using cell culture supernatant by an ELISA plate reader at $550 \mathrm{~nm}$ [24].

\section{Biochemical analysis}

The toxic effects of prescribed treatments on the livers and kidneys of mice were assessed by analysis of the aspartate aminotransferase (AST), alanine aminotransferase (ALT), alkaline phosphatase (ALP), creatinine (Cr), urea, sodium $(\mathrm{Na})$, and potassium $(\mathrm{K})$ in serum samples using Pishtaz Teb kit (Iran) according to the manufacturer's instructions.

\section{Hemolytic assay}

In vitro hemolytic activity was done by spectrophotometric method [25]. In this study, the fresh human blood samples obtained from returned unused blood bags in the blood bank (Iranian Blood Transfusion Organization) were used. A volume of $0.2 \mathrm{~mL}$ of the blood was mixed with $0.8 \mathrm{~mL}$ of the resveratrol and RNE $(50,100,200$, $400 \mu \mathrm{g} / \mathrm{mL}$ ). The mixture was incubated for $30 \mathrm{~min}$ at $37^{\circ} \mathrm{C}$ and then centrifuged at $1500 \mathrm{rpm}$ for $10 \mathrm{~min}$. The free hemoglobin in the supernatant was analyzed by UVVis spectrophotometer at $540 \mathrm{~nm}$. The PBS and distilled water (DW) were used as minimal and maximal hemolytic controls.

\section{Histopathological examination}

The toxicity of resveratrol $(40 \mathrm{mg} / \mathrm{kg} \mathrm{BW})$ and RNE $(20 \mathrm{mg} / \mathrm{kg} \mathrm{BW})$ on tissue were evaluated according to the observation of histological changes in liver, heart, and spleen of treated and untreated mice that described previously [5]. At day 28 of treatment, mice were euthanized and livers and kidneys were removed and their weights 
were recorded. Impression smears were prepared and fixed in $100 \%$ methanol to allow the determination of parasite burden and confirm infection. A small piece of all tissue was cut off, immersed in a $10 \%$ neutral buffered formalin solution, and processed routinely into paraffin wax. To identify histological changes, 4- $\mu \mathrm{m}$ tissue sections were stained with Hematoxylin and Eosin (H\&E) and analyzed under a light microscope. The severity of histological changes was also graded as severe, moderate, or mild.

\section{Apoptosis assay}

The promastigotes were cultured in RPMI medium supplemented with $15 \%$ heat-inactivated FBS in 96-well microtiter plate $\left(3 \times 10^{5}\right.$ parasites per well $)$ in the absence of resveratrol and RNE (as the negative control group) and in the presence of an indicated concentration of resveratrol and RNE. They were incubated at $24{ }^{\circ} \mathrm{C}$ for $24 \mathrm{~h}$. Then cells were washed twice with PBS and $1 \times 10^{5}$ cells were re-suspended in $100 \mu \mathrm{L}$ binding buffer and incubated with $5 \mu \mathrm{L}$ of Annexin V-FITC and propidium iodide (PI) as a counterstain for $15 \mathrm{~min}$ at room temperature in darkness, according to the manufacturer's instructions (BD Biosciences, San Diego, CA, USA). Finally, the percent of apoptotic and necrotic cells was evaluated by flow cytometry (Becton Dickinson) and data were analyzed using Flowjo software (version 7) [11].

\section{Cytotoxicity assay}

L929 cell line was seeded into 96-well microtiter plates (Nunc, Roskilde, Denmark) in DMEM (100 $\mu \mathrm{L})$ supplemented with $10 \%$ FBS and $1 \%$ penicillin-streptomycin solution. Cells then were incubated at $37^{\circ} \mathrm{C}$ in a humidity of $95 \%$ and $5 \% \mathrm{CO}_{2}$ for $24 \mathrm{~h}$. Resveratrol in concentrations of 100,200 , and $400 \mu \mathrm{g} / \mathrm{mL}$, RNE in concentrations of 100,200 , and $400 \mu \mathrm{g} / \mathrm{mL}, \mathrm{PVC}$, and PBS as the positive and negative controls, respectively were added to each well in triplicate. After $24 \mathrm{~h}$ of incubation time, $10 \mu \mathrm{L}$ of MTT solution was added to each well. After $3 \mathrm{~h}$ of incubation at $37^{\circ} \mathrm{C}$, the supernatant was removed and $100 \mu \mathrm{L}$ of DMSO was added. Finally, the absorbance at $570 \mathrm{~nm}$ was measured by a microtiter plate reader (BioTek ELX800, Winooski, VT, USA) and the viability was calculated by the below formula [21]:

$$
\text { Viability }(\%)=\frac{\text { ODTest }}{\text { ODControl }} \times 100
$$

\section{Statistical analysis}

All in vitro experiments were done in triplicate. The differences between mean values of the experimental groups were done by one-way analysis of variance (ANOVA) using SPSS version 23 software (SPSS Inc.,
Chicago, IL, USA). A value of $P<0.05$ was considered statistically significant.

\section{Results \\ Characterization}

The TEM images (Fig. 1a, b) showed that resveratrol and RNE were both spherical morphology. According to the results of DLS analysis, the average size and PDI of RNE were $110.1 \pm 14 \mathrm{~nm}$ (with mean intensity of 9.8\%; Fig. 1ce) and 0.23 , respectively. The surface charge and stability of the prepared nanoparticle were determined by zeta potential measurements.

Zeta potential is an important tool to indicate particle surface charge, which could be used to predict and control the stability of nano-suspensions. The average size and the zeta potential of resveratrol were $432.7 \pm 26 \mathrm{~nm}$ and $-12.1 \mathrm{mV}$, respectively. In contrast, the zeta potential value of RNE was found to be $-48.7 \mathrm{mV}$. According to the data, the negative potential is high enough to avoid the aggregation of nanoparticles and keep their dispersion system stable.

\section{In vitro activity}

In all concentrations, the inhibitory effects of resveratrol and RNE were dose and time-dependent. In all concentrations by increasing the time, the amounts of live promastigotes of $L$. major were decreased. In all times, the resveratrol and RNE showed significantly better effectiveness in comparison to the negative and even positive controls. After $12 \mathrm{~h}$ of treatment, resveratrol and RNE at the concentrations of $50,100,200$, and $400 \mu \mathrm{g} / \mathrm{mL}$ were significantly more effective than Amphotericin B $(P<0.05)$. After $24 \mathrm{~h}$ of treatment, resveratrol and RNE in all concentrations were significantly more effective than Amphotericin B $(P<0.05)$. Also, after $48 \mathrm{~h}$ of treatment, resveratrol at concentrations of 50,100, 200, and $400 \mu \mathrm{g} /$ $\mathrm{mL}$ and RNE at the concentrations of 100, 200, and $400 \mu \mathrm{g} / \mathrm{mL}$ showed better anti-leishmanial activity than positive control (Amphotericin B) but this difference was not statically significant $(P>0.05)$. The mortality rate of the parasite in all treatment groups after $72 \mathrm{~h}$ was similar to a positive control (Amphotericin B; $P>0.05$ ), otherwise significantly higher than negative control group (PBS) in all exposure times $(P<0.05$; Fig. 2$)$.

Furthermore, the $\mathrm{IC}_{50}$ values were calculated as 16.23 and $35.71 \mu \mathrm{g} / \mathrm{mL}$ for resveratrol and RNE, respectively (Fig. 3).

\section{In vivo activity}

The in vivo activities of different treatment groups were assessed for 28 days of intervention. According to the results in Fig. 4, the mean size of lesions decreased in the groups treated with resveratrol and RNE in comparison 


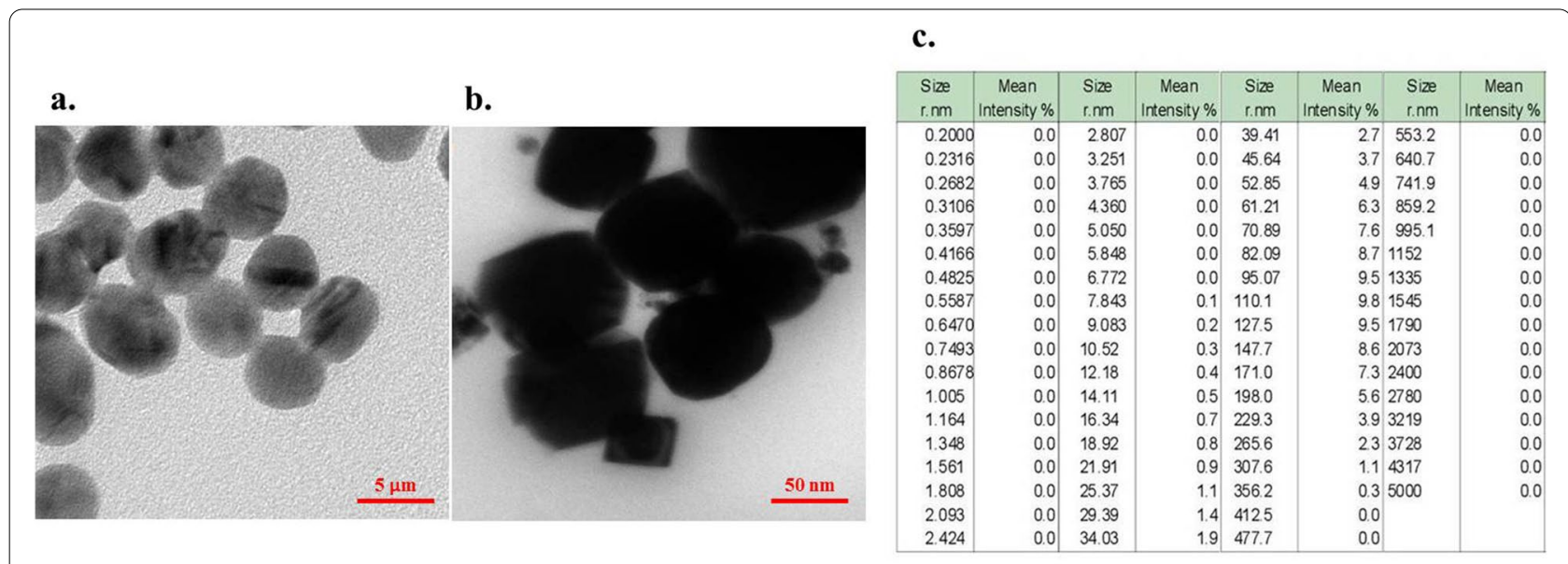

d.

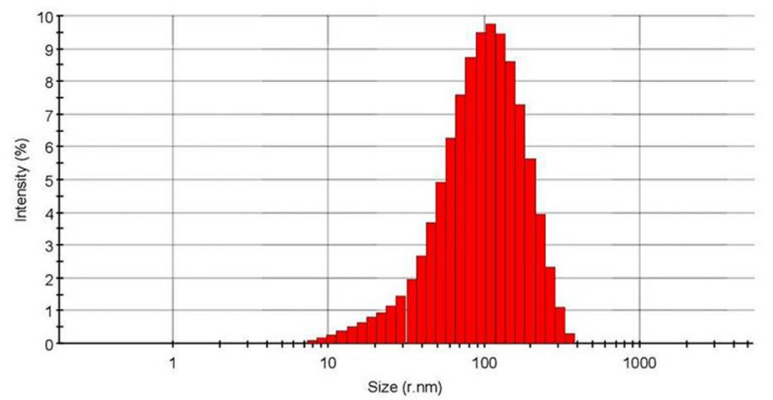

e.

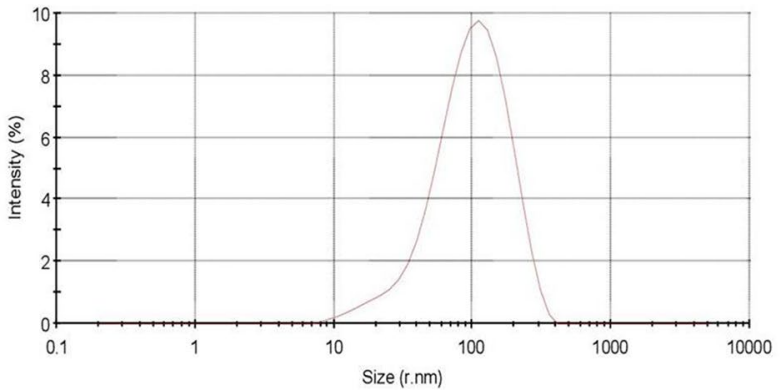

Fig. 1 Characterization of synthesized RNE: a) Transmission electron microscope micrograph of resveratol, b) Transmission electron microscope micrograph of RNE, c) Percentages of mean intensity of RNE size, d) Histogram of size distribution of synthesized RNE, e) The particle size distribution of RNE by DLS analysis

with the control group. After 7, 14, and 21 days of treatment, the differences between Amphotericin B and Resveratrol (at concentrations of 5,10 , and $15 \mathrm{mg} / \mathrm{kg} \mathrm{BW}$ ) and RNE (at concentrations of 5 and $10 \mathrm{mg} / \mathrm{kg} \mathrm{BW}$ ) were statically significant $(P<0.05)$ but, the concentrations of 20 and $40 \mathrm{mg} / \mathrm{kg} \mathrm{BW}$ of resveratrol and the concentrations of $20 \mathrm{mg} / \mathrm{kg} \mathrm{BW}$ of RNE showed similar efficacy to Amphotericin B $(P>0.05)$. After 28 days of treatment, all concentrations of resveratrol and RNE revealed better anti-leishmanial activity but the difference was not statically significant $(P>0.05)$. The mean lesion size in the negative control (PBS) after 28 days of intervention was 7.5 and $7.2 \mathrm{~mm}$, whereas it was $0.0 \mathrm{~mm}$ in groups treated with the $15 \mathrm{mg} / \mathrm{kg} \mathrm{BW}$ of resveratrol and $10 \mathrm{mg} / \mathrm{kg} \mathrm{BW}$ of RNE. The mean difference between treated and untreated controls was significant $(P<0.05)$. There are not significant differences between resveratrol and RNE with Amphotericin B as the positive control $(P>0.05)$.

\section{Anti-amastigote activity}

The anti-amastigote activity of Resveratrol and RNE in concentrations of $50,100,200$, and $400 \mu \mathrm{g} / \mathrm{mL}$ were assessed during 24 and $48 \mathrm{~h}$ in comparison to the control group. Our results in Table 1 indicated that Resveratrol and RNE in all concentrations significantly decreased the rates of macrophages infectivity and the number of amastigotes in macrophages after 24 and $48 \mathrm{~h}$ of incubation $(P<0.05)$. Resveratrol in the concentration of $400 \mu \mathrm{g} / \mathrm{mL}$ and RNE in the concentrations of 200 and $400 \mu \mathrm{g} / \mathrm{mL}$ showed significantly better anti-amastigote activity than Amphotericin B as the positive control $(P<0.05)$. RNE in concentrations of 100,200 , and $400 \mu \mathrm{g} / \mathrm{mL}$ were significantly more effective than Resveratrol $(P<0.05)$ but in the concentration of $50 \mu \mathrm{g} / \mathrm{mL}$ there is not any significant difference $(P>0.05)$.

\section{Determination of NO production}

The high concentrations of resveratrol $(\geq 200 \mu \mathrm{g} /$ $\mathrm{mL}$ ) decreased the production of $\mathrm{NO}$ and produced a high lower of this component compared with the control group (PBS: $7.23 \mu \mathrm{M}$ and DMSO: $6.73 \mu \mathrm{M}$ ). In addition, the production of NO-induced by resveratrol, RNE (at the concentrations of 200 and $400 \mu \mathrm{g} /$ $\mathrm{mL}$ ), and Amphotericin B were statistically different $(P>0.05$; Fig. 5). 

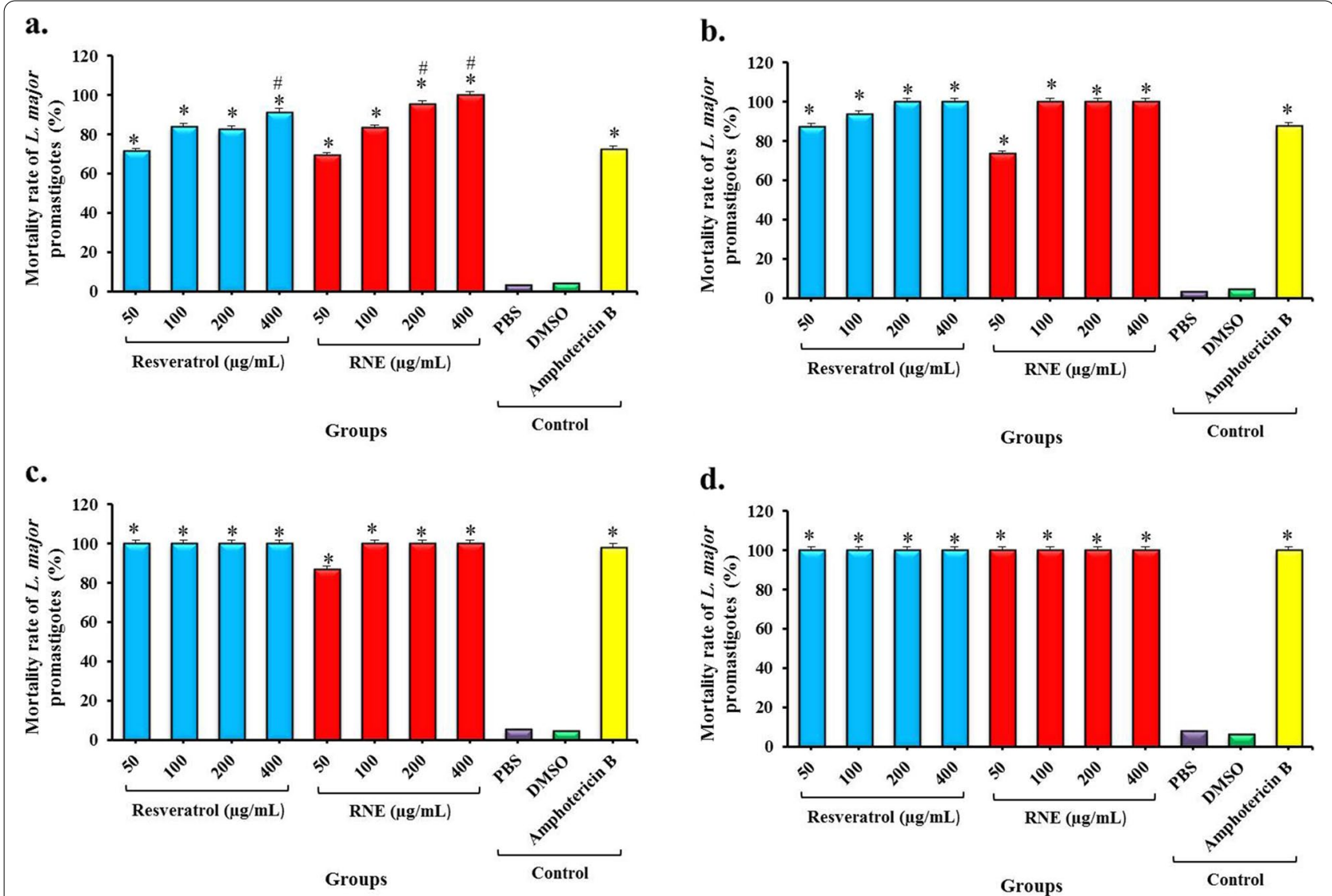

Fig. 2 The mortality rate of $L$. major promastigotes following treatment with different groups; a) after $12 \mathrm{~h}, \mathrm{~b}$ ) after $24 \mathrm{~h}, \mathrm{c})$ after $48 \mathrm{~h}$, and d) after $72 \mathrm{~h}$. *Significant differences according to the control group (PBS), $P<0.05$. \#Significant differences compared with Amphotericin $B, P<0.05$
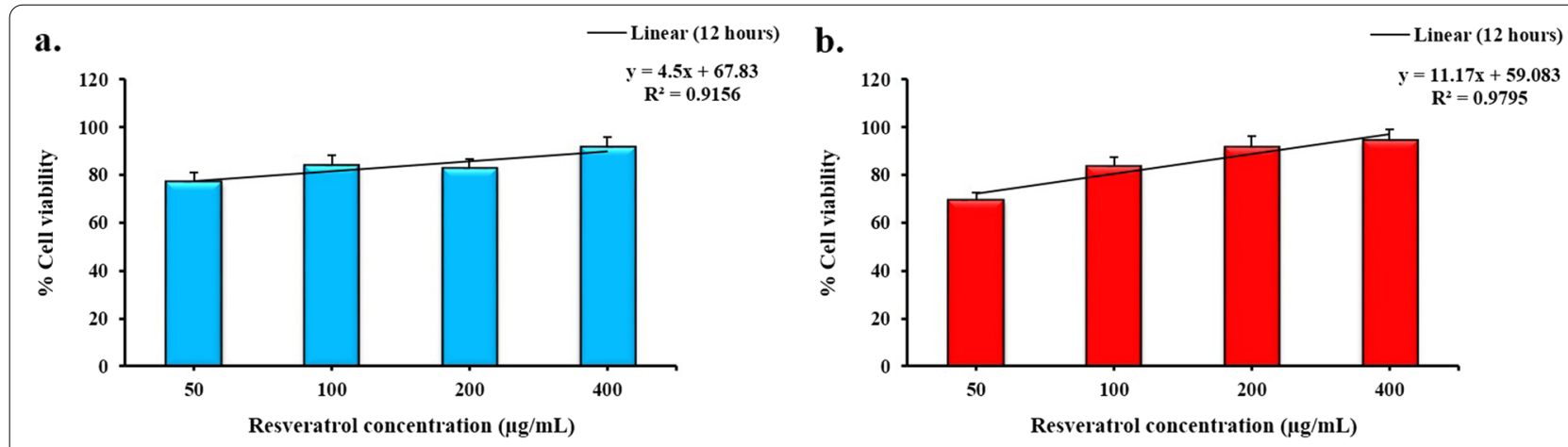

Fig. 3 Determination of the $I_{50}$ value of the resveratrol (a) and RNE (b) on promastigotes of L. major after $12 \mathrm{~h}$

\section{Biochemical analysis}

The biochemical parameters such as AST, ALT, and ALP enzymes, $\mathrm{Cr}$, urea, $\mathrm{Na}$, and $\mathrm{K}$ were evaluated in $\mathrm{BALB} / \mathrm{C}$ mice following treatment with different groups (Fig. 6ag). No significant differences were observed between the treated and control groups $(P>0.05$; Fig. 6$)$, except for the
AST test in group treated with Amphotericin B (Fig. 6a; $P<0.05)$.

\section{Hemolytic activity}

According to the results in Table 2, the hemolytic effects of resveratrol and RNE in highest concentration 

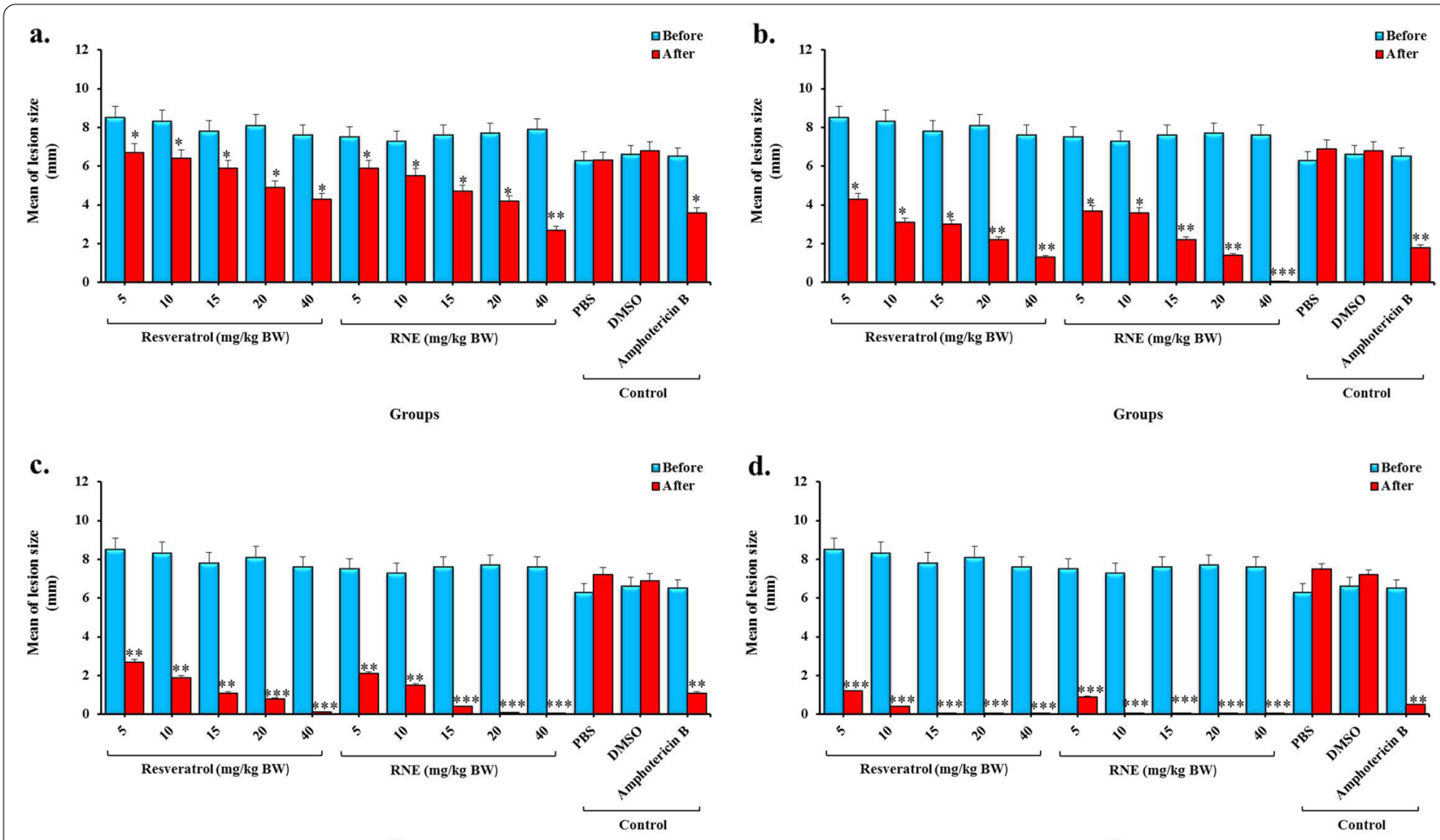

Groups

Groups

Fig. 4 The mean of lesion size BALB/C mice following treatment with different groups; a) after 7 days, b) after 14 days, c) after 21 days, and d) after 28 days. ${ }^{*}$ Significant differences according to the control group (PBS), $P<0.05,{ }^{* *} P<0.005$, ${ }^{* * *} P<0.0005$

Table 1 The percentage distribution of infected macrophages and mean number of amastigotes in each macrophage in the different experimental groups after 24 and $48 \mathrm{~h}$

\begin{tabular}{|c|c|c|c|c|c|c|c|}
\hline \multirow[t]{2}{*}{ Groups } & \multirow[t]{2}{*}{ Concentration } & $\begin{array}{l}\mathrm{MQ}^{\mathrm{a}} \\
\text { infectivity (\%) }\end{array}$ & $\begin{array}{l}\text { Number of } \\
\text { amastigotes }\end{array}$ & \multirow{2}{*}{$\begin{array}{l}\text { MQ infectivity } \\
(\%) \\
24 \mathrm{~h}\end{array}$} & \multirow[t]{2}{*}{$\begin{array}{l}\text { Number of } \\
\text { amastigotes }\end{array}$} & \multirow{2}{*}{$\begin{array}{l}\text { MQ infectivity } \\
(\%) \\
48 \mathrm{~h}\end{array}$} & \multirow[t]{2}{*}{$\begin{array}{l}\text { Number of } \\
\text { amastigotes }\end{array}$} \\
\hline & & \multicolumn{2}{|c|}{$\mathrm{O} \mathrm{h}$ (Before treatment) } & & & & \\
\hline \multirow[t]{4}{*}{ Resveratrol } & $50 \mu \mathrm{g} / \mathrm{mL}$ & 76.4 & 17.6 & $68.4^{*}$ & 12.5 & 55.3 & $9.8^{*}$ \\
\hline & $100 \mu \mathrm{g} / \mathrm{mL}$ & 81.0 & 18.3 & $56.2^{*}$ & 12.1 & $41.9^{*}$ & $9.5^{*}$ \\
\hline & $200 \mu \mathrm{g} / \mathrm{mL}$ & 78.3 & 18.0 & $42.6^{*}$ & $6.7^{*}$ & $35.5^{*}$ & $2.4^{*}$ \\
\hline & $400 \mu \mathrm{g} / \mathrm{mL}$ & 79.6 & 16.2 & $31.4^{*}$ & $3.3^{*}$ & $25.8^{*}$ & $0.5^{* *}$ \\
\hline \multirow[t]{4}{*}{ RNE } & $50 \mu \mathrm{g} / \mathrm{mL}$ & 78.4 & 15.8 & $67.8^{*}$ & $11.6^{*}$ & 53.8 & $6.7^{*}$ \\
\hline & $100 \mu \mathrm{g} / \mathrm{mL}$ & 87.5 & 17.3 & $54.2^{*}$ & $7.3^{*}$ & $43.0^{*}$ & $0.6^{* *}$ \\
\hline & $200 \mu \mathrm{g} / \mathrm{mL}$ & 84.5 & 17.6 & $34.3^{*}$ & $2.6^{*}$ & $26.2^{*}$ & $0.0^{* *}$ \\
\hline & $400 \mu \mathrm{g} / \mathrm{mL}$ & 77.0 & 17.0 & $22.5^{* *}$ & $0.0^{* *}$ & $17.4^{* *}$ & $0.0^{* *}$ \\
\hline Amphotericin B & $20 \mu \mathrm{g} / \mathrm{mL}$ & 73.4 & 15.7 & $34.5^{*}$ & $4.3^{*}$ & $42.7^{*}$ & $0.4^{* *}$ \\
\hline PBS & $7.23 \mu \mathrm{M}$ & 74.5 & 16.3 & 81.7 & 15.2 & 63.2 & 14.6 \\
\hline DMSO & $6.73 \mu \mathrm{M}$ & 80.3 & 16.3 & 73.5 & 13.6 & 67.7 & 12.9 \\
\hline
\end{tabular}

a: Macrophage, *Significant differences according to the control group (PBS), $P<0.05$, ${ }^{* *} P<0.005$

were $25.2 \pm 5.3 \%$ and $15.4 \pm 3.5 \%$, respectively, while; Amphotericin B showed 21.6\% hemolytic effect compared with the control group $(P<0.05)$.

\section{Histopathology findings}

H\&E staining showed that resveratrol and RNE similarly to the control, did not cause significant pathological changes in the heart, liver, and spleen (Fig. 7). 


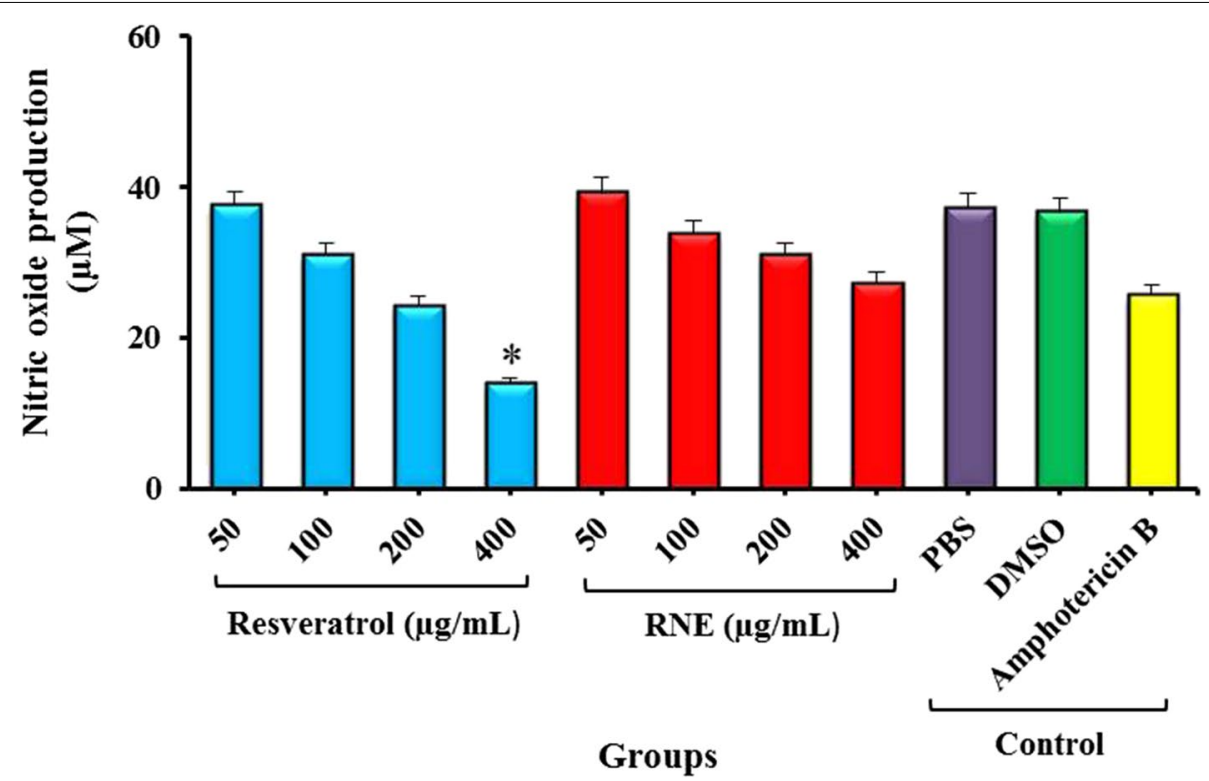

Fig. 5 The production of nitric oxide following treatment with different groups. *Significant differences according to the control group (PBS), $P<0.05$

\section{Flow cytometry analysis}

The treatment of promastigotes at two concentrations of resveratrol (200 and $400 \mu \mathrm{g} / \mathrm{mL}$ ) and RNE (200 and $400 \mu \mathrm{g} / \mathrm{mL}$ ) for $24 \mathrm{~h}$ resulted in necrotic and apoptotic effects in the parasites and the representative histograms of the flow cytometry (Fig. 8) showed that the viability rates of cells to be $87.9 \%$ ( $200 \mu \mathrm{g} / \mathrm{mL}$ resveratrol), $71.4 \%$ (400 $\mathrm{\mu g} / \mathrm{mL}$ resveratrol), 93.2\% (200 $\mu \mathrm{g} / \mathrm{mL} \mathrm{RNE})$, and 82.1\% (400 $\mu \mathrm{g} / \mathrm{mL} \mathrm{RNE})$. According to the results in Fig. 8, there were no significant differences between the treatment groups $(P>0.05)$.

\section{Cytotoxicity activity}

The tetrazolium-based colorimetric MTT assay showed that resveratrol and RNE in all concentrations had lower toxicity effects on the $\mathrm{L} 929$ cell line viability after $24 \mathrm{~h}$ in comparison to the control group $(P>0.05$; Table 3$)$. Furthermore, resveratrol in concentrations of 100 and $200 \mu \mathrm{g} / \mathrm{mL}$ and RNE in concentrations of 100,200 , and $400 \mu \mathrm{g} / \mathrm{mL}$ revealed lower cytotoxicity effects in comparison to the Amphotericin $\mathrm{B}$ as a conventional drug and these differences were statically significant $(P<0.05)$. Although resveratrol in concentration of $400 \mu \mathrm{g} / \mathrm{mL}$ had lower cytotoxicity effect in comparison to the Amphotericin $\mathrm{B}$, it was not statically significant $(P>0.05)$.

\section{Discussion}

The anti-leishmanial effects of resveratrol and RNE in different concentrations were assessed in the present in vitro and in vivo study. Conventional treatments for leishmaniasis indicate too many limitations, comprising high costs, inaccessibility, high toxicity with many severe adverse side effects, and drug resistance $[7,22]$. Therefore, designing accessible, low cost, and safe therapies is essentially required. Natural products due to the large structural diversity of secondary metabolites and novel chemical structures; conventionally play a crucial role in the exploration of new therapeutics and are valuable sources over centuries [26]. Resveratrol, a type of Stilbene compound, is reported as a therapeutic agent for many infectious diseases which has been extensively used in many preclinical studies [27-30].

Resveratrol can inhibit ribonucleotide reductase, cell DNA polymerase, and can disrupt the cell cycle [31]. Furthermore, several investigations have also indicated antimicrobial activities of resveratrol against different pathogens $[14,28]$. For instance, Docherty et al. evaluated the effects of topically applied resveratrol on cutaneous herpes simplex virus (HSV) infections caused by an acyclovir-resistant virus in hairless mice and the results indicated that resveratrol inhibits HSV lesion formation in the skin of mice without any apparent dermal toxicity such as scaling, erythema, lichenification, crusting, and excoriation [32]. A study conducted by Jung et al. applied resveratrol to assess its antifungal effects and the results indicated that resveratrol is effective against $\mathrm{Can}$ dida albicans with the IC50 value of $10-20 \mu \mathrm{g} / \mathrm{mL}$ with no hemolytic activity against human erythrocytes [33]. Similar results by Costa et al., reported that resveratrol at the concentration of $10 \mathrm{mg} / \mathrm{mL}$ significantly decreased 

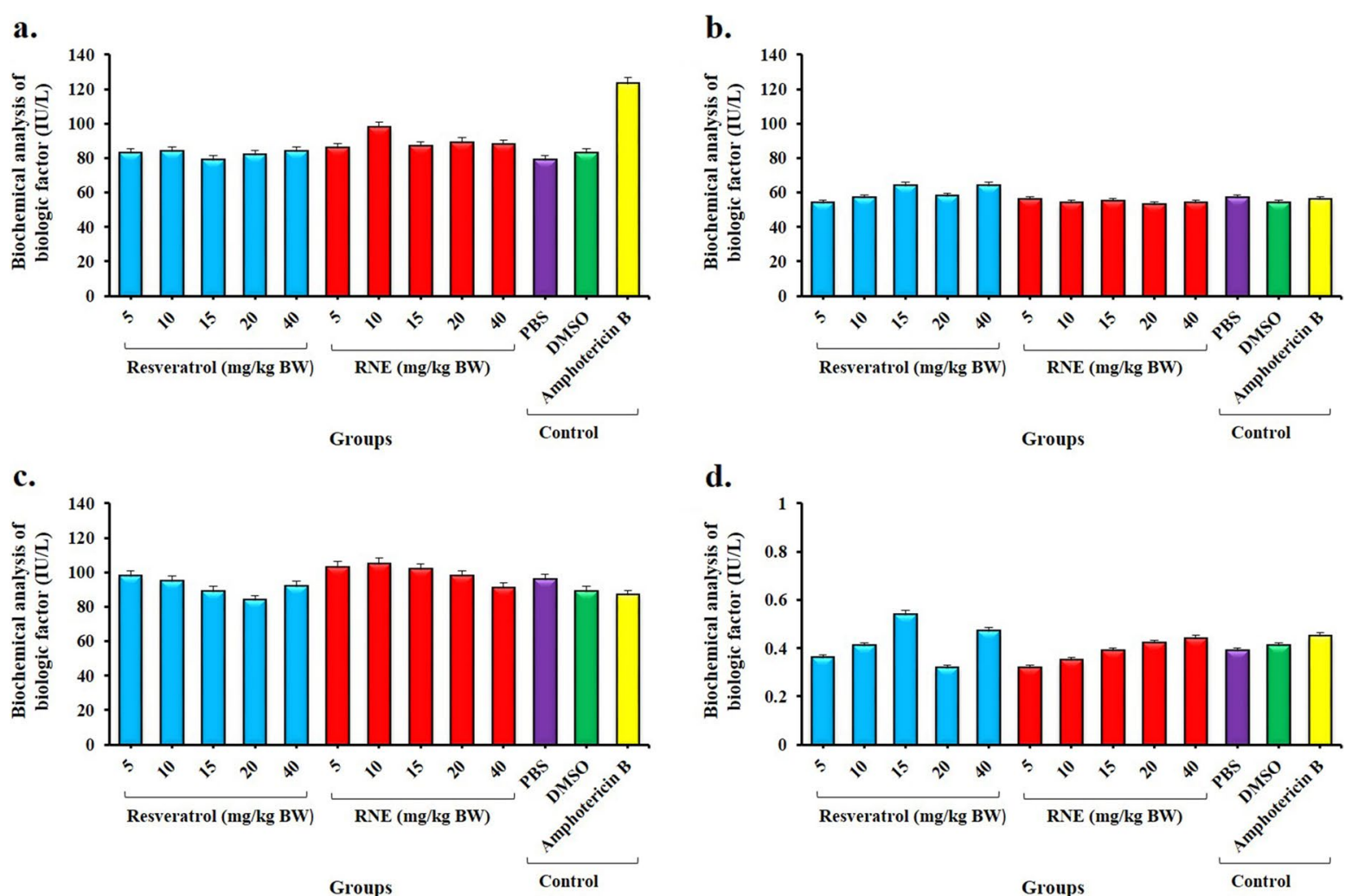

d.
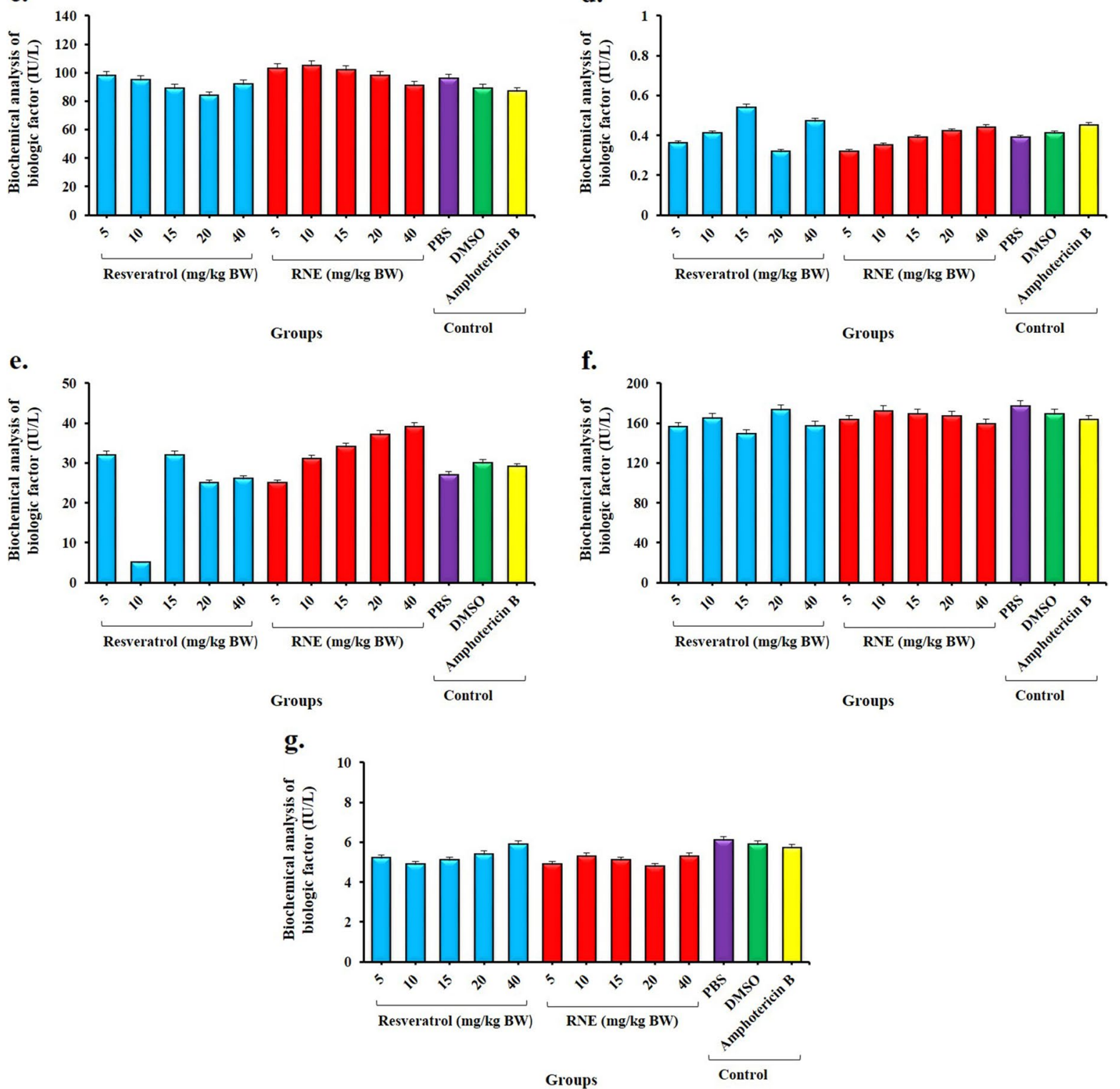

Fig. 6 Biochemical analysis of some biologic factors in BALB/c mice following treatment with different groups; a) Aspartate aminotransferase (AST), b) Alanine aminotransferase (ALT), c) alkaline phosphatase (ALP), d) Creatinine (Cr), e) Urea, f) Sodium (Na), and g) Potassium (K). ${ }^{*}$ Significant differences according to the control group, $P<0.05$ 
Table 2 The hemolytic effects of the treatment groups

\begin{tabular}{|c|c|c|c|c|c|c|c|c|c|}
\hline \multirow[t]{2}{*}{ Hemolytic assay } & \multicolumn{3}{|c|}{ Resveratrol $(\mu \mathrm{g} / \mathrm{mL})$} & \multicolumn{3}{|c|}{ RNE ( $\mu \mathrm{g} / \mathrm{mL})$} & \multirow[t]{2}{*}{ Amphotericin B } & \multirow[t]{2}{*}{ PBS } & \multirow[t]{2}{*}{$\mathrm{DW}^{\mathrm{a}}$} \\
\hline & 100 & 200 & 400 & 100 & 200 & 400 & & & \\
\hline Percent (\%) & $17.5 \pm 2.4$ & $19.6 \pm 3.7$ & $25.2 \pm 5.3$ & $9.4 \pm 2.1$ & $11.31 \pm 2.6$ & $15.41 \pm 3.1$ & $21.6 \pm 5.3$ & $2.3 \pm 0.3$ & $43.4 \pm 7.4$ \\
\hline$P$ value & $<0.05$ & $<0.005$ & $<0.005$ & $<0.05$ & $<0.05$ & $<0.05$ & $<0.005$ & & $<0.005$ \\
\hline
\end{tabular}

${ }^{\mathrm{a}} D W$ Distilled water

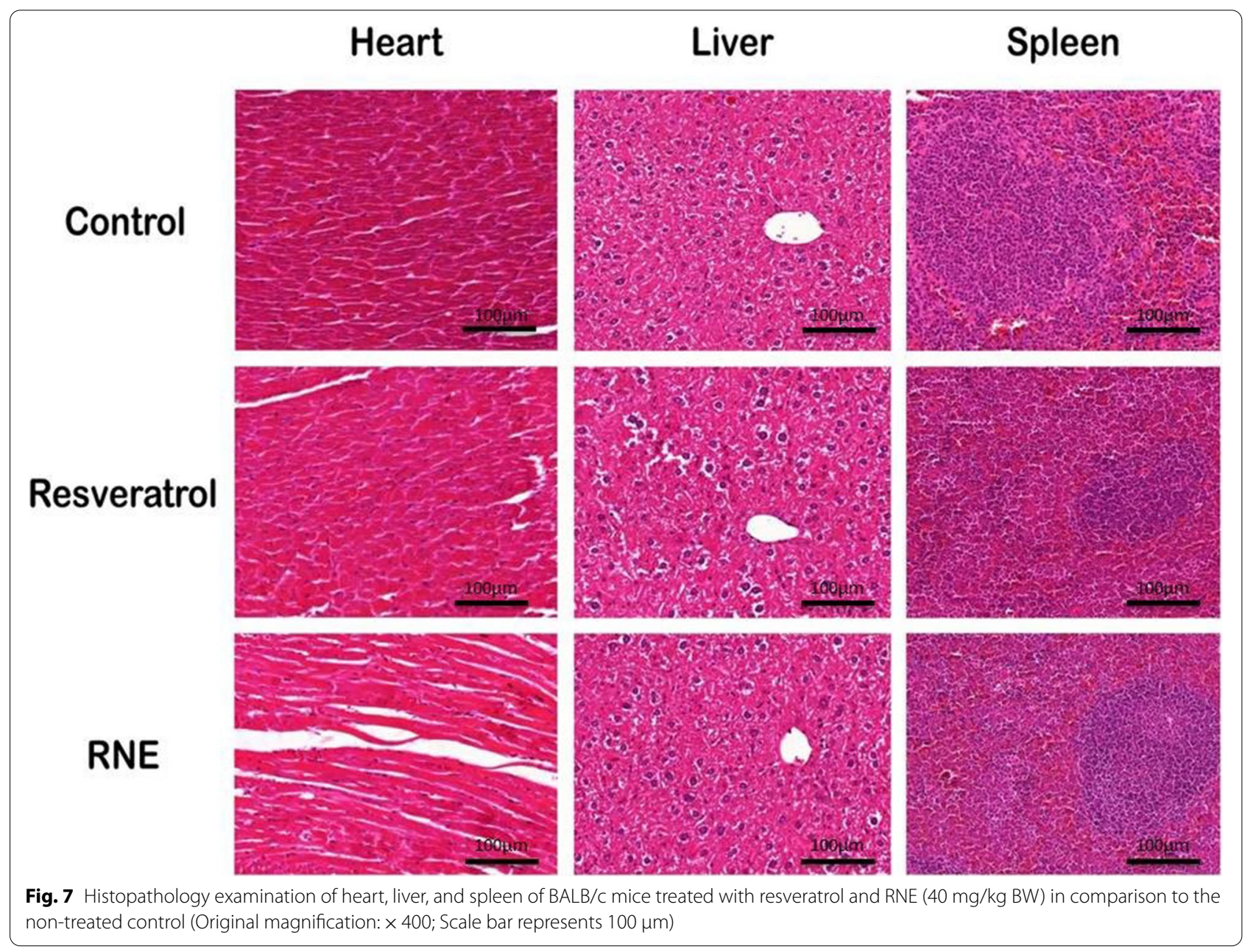

the spores of Nosema ceranae in honey bees [34]. In some similar works resveratrol has been evaluated for its anti-parasitic activity against Hymenolepis diminuta [35], Leishmania spp. [17, 18], Plasmodium falciparum [36], and revealed acceptable outcomes. Kedzierski et al. investigated the effects of resveratrol on L. major promastigotes and intracellular amastigotes stages and the results indicated that this compound has brilliant antipromastigote effects but the intracellular amastigote was resistant to resveratrol at concentrations of 10,50 , and $100 \mu \mathrm{g} / \mathrm{mL}$ [17]. In this study, the concentration of
$100 \mu \mathrm{g} / \mathrm{mL}$ was able to eliminate $100 \%$ of promastigotes in $48 \mathrm{~h}$. In a similar study conducted by Ferreira et al., resveratrol decreased the numbers of parasite in vitro, reduced the mitochondrial potential, increased the percentage of promastigotes in the sub-G0/G1 phase of the cell cycle and the nuclear magnetic resonance (NMR) spectroscopy analysis revealed that resveratrol elevated $\mathrm{CH} 2$-to- $\mathrm{CH} 3$ ratio and choline peak [16]. All these results indicated resveratrol killed the parasite. In an in vitro study by Alves Passos et al., oxyresveratrol showed antileishmanial effects on $L$. amazonensis promastigotes with 


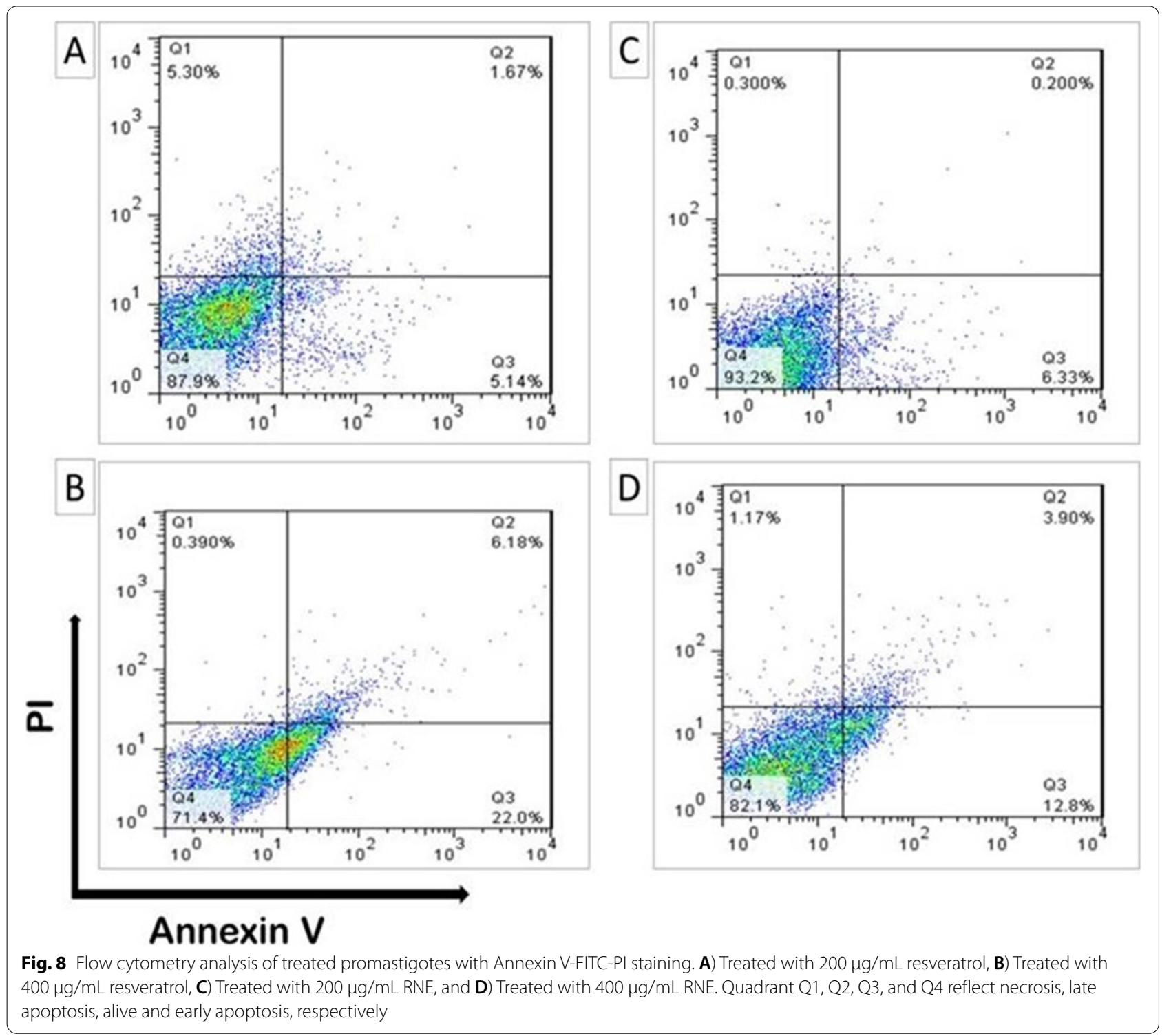

an IC50 value of $65 \mu \mathrm{g} / \mathrm{mL}$ [37]. So, we could conclude that both resveratrol and RNE were more effective than oxyresveratrol and/or L. amazonensis promastigotes was more resistant than L. major. All studies examined the anti-parasitic effects in vitro while this study was conducted in an in vivo situation for the first time. Another very important point is the type of study. The fact that a drug has an extraordinary anti-parasitic effect in vitro cannot guarantee its effectiveness in vivo.

In the present study, resveratrol and $\operatorname{RNE}(50,100,200$, and $400 \mu \mathrm{g} / \mathrm{mL}$ ) were used for evaluation their anti-promastigote and anti-amastigote effects. Our results were compared to the Amphotericin B as the positive control and there were not any significant differences between

Table 3 The cytotoxic effects of the treatment groups in comparison to the control groups

\begin{tabular}{|c|c|c|c|c|c|c|c|c|c|}
\hline \multirow[t]{2}{*}{ Cytotoxicity assay } & \multicolumn{3}{|c|}{ Resveratrol $(\mu \mathrm{g} / \mathrm{mL})$} & \multicolumn{2}{|c|}{$\operatorname{RNE}(\mu \mathrm{g} / \mathrm{mL})$} & \multirow[b]{2}{*}{400} & \multirow[t]{2}{*}{ Amphotericin B } & \multirow[t]{2}{*}{ PBS } & \multirow[t]{2}{*}{$\mathrm{PVC}^{\mathrm{a}}$} \\
\hline & 100 & 200 & 400 & 100 & 200 & & & & \\
\hline Percent (\%) & $8.4 \pm 1.6$ & $14.8 \pm 3.0$ & $18.7 \pm 4.6$ & $11.4 \pm 3.3$ & $13.2 \pm 2.9$ & $15.12 \pm 2.3$ & $19.5 \pm 0.6$ & $5.3 \pm 1.6$ & $37.6 \pm 5.3$ \\
\hline$P$ value & $<0.05$ & $<0.05$ & $<0.005$ & $<0.05$ & $<0.05$ & $<0.005$ & $<0.005$ & & $<0.005$ \\
\hline
\end{tabular}

${ }^{\text {a Polyvinyl chloride }}$ 
the results of resveratrol and RNE (200 and $400 \mu \mathrm{g} / \mathrm{mL}$ ) and Amphotericin B.

The IC50 values were calculated as 16.23 and $35.71 \mu \mathrm{g} /$ $\mathrm{mL}$ for resveratrol and RNE, respectively. The most interesting point in this study was that resveratrol and RNE at the concentration of 200 and $400 \mu \mathrm{g} / \mathrm{mL}$ significantly indicate more effectiveness in comparison to the Amphotericin $\mathrm{B}$ as the conventional treatment, as well as at a concentration of $100 \mu \mathrm{g} / \mathrm{mL}$ also had a better effect than other studies.

Inhibition of tyrosine kinase activity in different malignancies, activation of the caspase 3 and 7 , a decrease of the IL-17 production and consequently activation of the human mononuclear cells, decrease prostaglandin E2 (PGE2) production, anti-inflammatory and antioxidant activities are reported caused by resveratrol in the previous studies [38, 39].

The effectiveness of a drug will be valuable when it does not have a toxic effect. Unfortunately, conventional medications used against various pathogens have irreversible side effects. That's why the search for alternatives to these drugs and the introduction of drugs with better efficacy and less toxicity, and preferably derived from natural compounds, is one of the priorities of the health system in the world. The effects of resveratrol on leishmaniasis lesions in vivo have also been investigated and its antileishmanial results have been confirmed. Furthermore, the toxicity of the drug has been investigated in vivo, and the results of pathological tests have shown that the resveratrol at the concentration of $40 \mathrm{mg} / \mathrm{kg} \mathrm{BW}$ had no toxic effect on the liver, heart, and spleen tissue of female $\mathrm{BALB} / \mathrm{c}$ mice.

The production of NO by infected macrophages during down-regulation of the inducible NO synthase (iNOS) is one of the most important anti-parasitic mechanisms. The NO interacts with the NADPHoxidase and causes cytotoxicity effects against microorganisms such as parasites in different stages of infections. In the current study, the production of the NO by macrophages was analyzed and the results indicated that resveratrol at the concentrations of 50 and $100 \mu \mathrm{g} / \mathrm{mL}$ and RNE at the concentrations of 50,100 , 200 , and $400 \mu \mathrm{g} / \mathrm{mL}$ decreased the NO production even more than Amphotericin B $(P<0.05)$. Similar to our results, Alves Passos et al. revealed that piceatannol and pterostilbene decrease NO production by LPSstimulated macrophages [37]. Furthermore, in a study conducted by Qureshi et al. resveratrol and pterostilbene inhibited the expression of TNF- $\alpha$, IL-1 $\beta$, IL- 6 , and iNOS genes in LPS-stimulated RAW 264.7 cells and LPS-stimulated peritoneal macrophages from both C57BL/6 and BALB/c mice [40].
Elgendy et al. declared that resveratrol at the concentration of $20 \mathrm{mg} / \mathrm{kg}$ BW once daily for two weeks reduces oxidative damage and inflammation in mice infected with Trichinella spiralis [30]. We evaluated the probably toxic effects of the drugs used in the current study by assessing the cytotoxicity on L929 cell line, hemolysis on human red blood cells, and also the biochemical parameters to find possibly toxic effects and all these results confirmed the safety of resveratrol and RNE.

Overall, the results of the current study recommended that resveratrol in vitro study at the concentrations of 25,50 , and $100 \mu \mathrm{g} / \mathrm{mL}$ after 72,48 and $24 \mathrm{~h}$, respectively and in vivo study at the concentration of $10 \mathrm{mg} / \mathrm{kg} \mathrm{BW}$ after 28 days are the most effective dose and time. Also, RNE in vitro study at concentrations of 50 and $100 \mu \mathrm{g} /$ $\mathrm{mL}$ after 72 and $24 \mathrm{~h}$, respectively and in vivo study at concentration of $10 \mathrm{mg} / \mathrm{kg} \mathrm{BW}$ after 28 days are the most effective dose and time.

\section{Conclusion}

The results indicated that there were no significant differences between the anti-leishmanial effects of resveratrol and RNE. Both forms of these compounds at the concentrations of 100,200 , and $400 \mu \mathrm{g} / \mathrm{mL}$ showed better efficacy than Amphotericin B by both in vitro and in vivo studies. The cytotoxicity and hemolysis effects were less than Amphotericin B, no biochemical changes were observed, and all these findings declare that resveratrol and RNE are not toxic and are safe for mammalian cells. Resveratrol is delivered from natural products and also, has been commonly accessible, easily prepared, and lowpriced. Therefore, resveratrol is highly recommended as a good candidate for the natural leishmanicidal agent. The results of our study recommended that resveratrol in in vitro study at the concentrations of 25,50 , and $100 \mu \mathrm{g} /$ $\mathrm{mL}$ after 72,48 , and $24 \mathrm{~h}$, respectively and in in vivo study at the concentration of $10 \mathrm{mg} / \mathrm{kg} / \mathrm{BW}$ after 28 days were the most effective dose and time. Also, RNE in in vitro study at the concentrations of 50 and $100 \mu \mathrm{g} / \mathrm{mL}$ after 72 and $24 \mathrm{~h}$, respectively, and in in vivo study at the concentration of $10 \mathrm{mg} / \mathrm{kg} / \mathrm{BW}$ after 28 days are the most effective dose and time.

\section{Abbreviations \\ ALP: Alkaline phosphatase; ALT: Alanine aminotransferase; AST: Aspartate aminotransferase; CL: Cutaneous leishmaniasis; DMEM: Dulbecco's Modified Eagles Medium; RNE: Resveratrol nanoemulsion; RPMI: Roswell Park Memorial Institute; PVC: Polyvinyl chloride.}

\section{Acknowledgements}

The authors of this study would like to express their deep thanks to all laboratory staff in Isfahan University of Medical Sciences and Toxoplasma Research Center at Mazandaran University of Medical Sciences. 
All methods were performed in accordance with the relevant guidelines and regulations.

\section{Authors' contributions}

Conceptualization: BRE, SHH, MF, ZS, PM. Formal analysis: HH, AN. Methodology: PM, HH, BRE. Project administration: ZS, MF, SHH. Resources: HH, BRE. Supervision: ZS, SHH, MF. Writing of original draft: BRE, PM, MP. Design the figures: MP. Writing—review \& editing: BRE, MF, PM, AN, and MP. All authors reviewed the manuscript.

\section{Funding}

This work was supported by the Skin Diseases and Leishmaniasis Research Center, Isfahan University of Medical Sciences, Isfahan, Iran [Grant No: IR.MUI. MED.REC.1399.545 and IR.MUI.MED.REC.1399. 582].

\section{Availability of data and materials}

All data generated or analysed during this study are included in this published article.

\section{Declarations}

\section{Ethics approval and consent to participate}

The ethical approval for trials using experimental animals was obtained from the Ethics Committee of Research of Isfahan University of Medical Sciences (Isfahan, Iran) with the ethical code including IR.MUI.MED.REC.1399.582 for in vivo study and IR.MUI.MED.REC.1399.545 for in vitro study. All methods were carried out in in adherence to international and guidelines for ethical conduct in the care and use of animals. The study was carried out in compliance with the ARRIVE guidelines.

\section{Consent for publication}

Not applicable

\section{Competing interests}

The authors of declare that there is no conflict of interest.

\section{Author details}

${ }^{1}$ Skin Diseases and Leishmaniasis Research Center, Isfahan University of Medical Sciences, Isfahan, Iran. ${ }^{2}$ Department of Parasitology and Mycology, School of Medicine, Tonekabon Branch, Islamic Azad University, Tonekabon, Iran. ${ }^{3}$ Dental Research Center, Dentistry Research Institute, Tehran University of Medical Sciences, Tehran, Iran. ${ }^{4}$ Toxoplasma Research Center, Department of Parasitology, Iranian National Registry Center for Toxoplasmosis (INRCT), School of Medicine, Mazandaran University of Medical Sciences, Sari, Iran. ${ }^{5}$ Skin Diseases and Leishmaniasis Research Center, Department of Parasitology and Mycology, School of Medicine, Isfahan University of Medial Sciences, Isfahan, Iran. ${ }^{6}$ Immunogenetic Research Center, Faculty of Medicine and Amol Faculty of Paramedical Sciences, Mazandaran University of Medical Sciences, Sari, Iran. ${ }^{7}$ Department of Parasitology, School of Paramedical, Ilam University of Medical Sciences, Ilam, Iran.

Received: 29 July 2021 Accepted: 27 January 2022

Published online: 15 February 2022

\section{References}

1. Alvar J, Vélez ID, Bern C, Herrero M, Desjeux P, Cano J, et al. Leishmaniasis worldwide and global estimates of its incidence. PloS one. 2021;7(5):1-12.

2. Romero G, Guerra M, Paes MG, Macedo VO. Comparison of cutaneous leishmaniasis due to Leishmania (Viannia) braziliensis and L.(V.) guyanensis in Brazil: therapeutic response to meglumine antimoniate. The American journal of tropical medicine and hygiene. 2001;65(5):456-65.

3. Mahdavi SA, Javadian B, Barzegari S, RahimiEsboei B, Moosazadeh M. Epidemiological Study and Geographical Distribution of Cutaneous Leishmaniasis in Golestan Province, 2014-2016. Journal of Mazandaran University of Medical Sciences. 2020;29(181):125-30.

4. Firooz A, Mortazavi H, Khamesipour A, Ghiasi M, Abedini R, Balighi K, et al. Old world cutaneous leishmaniasis in Iran: clinical variants and treatments. J Dermatolog Treat. 2021;32(7):673-83.
5. Badirzadeh A, Heidari-Kharaji M, Fallah-Omrani V, Dabiri H, Araghi A, SalimiChirani A. Antileishmanial activity of Urtica dioica extract against zoonotic cutaneous leishmaniasis. Plos Neglected Tropical Diseases. 2020;14(1):e0007843.

6. Norouzinezhad F, Ghaffari F, Norouzinejad A, Kaveh F, Gouya MM. Cutaneous leishmaniasis in Iran: Results from an epidemiological study in urban and rural provinces. Asian Pac J Trop Biomed. 2016;6(7):614-9.

7. Croft S, Olliaro P. Leishmaniasis chemotherapy_challenges and opportunities. Clin Microbiol Infect. 2011;17(10):1478-83.

8. Den Boer M, Argaw D, Jannin J, Alvar J. Leishmaniasis impact and treatment access. Clin Microbiol Infect. 2011;17(10):1471-7.

9. Haldar AK, Sen P, Roy S. Use of antimony in the treatment of leishmaniasis: current status and future directions. Mol Biol Int. 2011;2011:1-23.

10. Date AA, Joshi MD, Patravale VB. Parasitic diseases: liposomes and polymeric nanoparticles versus lipid nanoparticles. Adv Drug Deliv Rev. 2007;59(6):505-21.

11. Pourhajibagher M, Rahimi-Esboei B, Hodjat M, Bahador A. Sonodynamic excitation of nanomicelle curcumin for eradication of Streptococcus mutans under sonodynamic antimicrobial chemotherapy: enhanced anti-caries activity of nanomicelle curcumin. Photodiagnosis Photodyn Ther. 2020;30:1-7

12. Golami S, Rahimi-Esboei B, Mousavi P, Marhaba Z, Youssefi MR, Rahimi MT. Survey on efficacy of chloroformic extract of Artemisia annua against Giardia lamblia trophozoite and cyst in vitro. J Parasit Dis. 2016:40(1):88-92.

13. Salehi B, Mishra AP, Nigam M, Sener B, Kilic M, Sharifi-Rad M, Fokou PVT, Martins N, Sharifi-Rad J. Resveratrol: A double-edged sword in health benefits. Biomedicines. 2018;6(3):91.

14. Colica C, Milanović M, Milić N, Aiello V, De Lorenzo A, Abenavoli L. A systematic review on natural antioxidant properties of resveratrol. Natural Product Communications. 2018;13(9):1934578X1801300923.

15. Duarte A, Martinho A, Luís Â, Figueiras A, Oleastro M, Domingues FC, Silva F. Resveratrol encapsulation with methyl- $\beta$-cyclodextrin for antibacterial and antioxidant delivery applications. LWT-Food Science and Technology. 2015:63(2):1254-60.

16. Ferreira C, Soares DC, do Nascimento MTC, Pinto-da-Silva LH, Sarzedas CG, Tinoco LW, Saraiva EM. Resveratrol is active against Leishmania amazonensis in vitro effect of its association with amphotericin B. Antimicrobial agents and chemotherapy. 2014;58(10):6197-208.

17. Kedzierski L, Curtis JM, Kaminska M, Jodynis-Liebert J, Murias M. In vitro antileishmanial activity of resveratrol and its hydroxylated analogues against Leishmania major promastigotes and amastigotes. Parasitol Res. 2007;102(1):91-7.

18. Rauf A, Imran M, Butt MS, Nadeem M, Peters DG, Mubarak MS. Resveratrol as an anti-cancer agent: A review. Crit Rev Food Sci Nutr. 2018:58(9):1428-47.

19. Zhao P, Sui BD, Liu N, Lv YJ, Zheng CX, Lu YB, Huang WT, Zhou CH, Chen J, Pang DL. Anti-aging pharmacology in cutaneous wound healing: effects of metformin, resveratrol, and rapamycin by local application. Aging Cell. 2017;16(5):1083-93.

20. Lee J-H, Kim Y-G, Raorane CJ, Ryu SY, Shim J-J, Lee J. The anti-biofilm and anti-virulence activities of trans-resveratrol and oxyresveratrol against uropathogenic Escherichia coli. Biofouling. 2019;35(7):758-67.

21. Choi AJ, Jo Y, Cho YJ, Kim TE, Kim CT. Preparation and characterization of resveratrol nanoemulsions stabilized by self-assembly and complex coacervation consisting of sodium alginate, chitosan, and $\beta$-Cyclodextrin. Food Engineering Progress. 2017;21(3):215-24.

22. Esboei BR, Mohebali M, Mousavi P, Fakhar M, Akhoundi B. Potent antileishmanial activity of chitosan against Iranian strain of Leishmania major (MRHO/IR/75/ER): In vitro and in vivo assay. J Vector Borne Dis. 2018;55(2):111.

23. Saha S, Mondal S, Ravindran R, Bhowmick S, Modak D, Mallick S, Rahman M, Kar S, Goswami R, Guha SK. IL-10-and TGF- $\beta$-mediated susceptibility in kala-azar and post-kala-azar dermal leishmaniasis: the significance of amphotericin B in the control of Leishmania donovani infection in India. J Immunol. 2007;179(8):5592-603.

24. Araújo JL, Bastos RS, Santos GT, de Moraes Alves MM, Figueiredo KA, de Sousa LA, Passos ING, de AmorimCarvalho FA, Lima FDCA, Rocha JA. Molecular Docking and Evaluation of Antileishmania Activity of a Ruthenium Complex with Epiisopiloturine and Nitric Oxide. Journal of Biosciences and Medicines. 2020;8(5):42-53. 
25. Pszenny V, Ehrenman K, Romano JD, Kennard A, Schultz A, Roos DS, Grigg ME, Carruthers VB, Coppens I. A lipolytic lecithin: cholesterol acyltransferase secreted by Toxoplasma facilitates parasite replication and egress. J Biol Chem. 2016;291(8):3725-46.

26. Abdelmohsen UR, Balasubramanian S, Oelschlaeger TA, Grkovic T, Pham NB, Quinn RJ, Hentschel U. Potential of marine natural products against drug-resistant fungal, viral, and parasitic infections. Lancet Infect Dis. 2017;17(2):e30-41.

27. Roy B, Giri BR. a-Viniferin and resveratrol induced alteration in the activities of some energy metabolism related enzymes in the cestode parasite Raillietina echinobothrida. Acta Trop. 2016;154:102-6.

28. Campo VA. Comparative effects of histone deacetylases inhibitors and resveratrol on Trypanosoma cruzi replication, differentiation, infectivity and gene expression. Int J Parasitol Drugs Drug Resist. 2017;7(1):23-33.

29. Vilar-Pereira G, Carneiro VC, Mata-Santos H, Vicentino AR, Ramos IP, Giarola NL, Feijo DF, Meyer-Fernandes JR, Paula-Neto HA, Medei E. Resveratrol reverses functional chagas heart disease in mice. PLoS pathogens. 2016;12(10):e1005947.

30. Elgendy D, Othman A, Saad MH, Soliman N, Mwafy S. Resveratrol reduces oxidative damage and inflammation in mice infected with Trichinella spiralis. J Helminthol. 2020;94:1-10.

31. Nana AW, Wu SY, Yang Y-CS, Chin Y-T, Cheng T-M, Ho Y, Li W-S, Liao Y-M, Chen Y-R, Shih Y-J. Nano-diamino-tetrac (NDAT) enhances resveratrolinduced antiproliferation by action on the RRM2 pathway in colorectal cancers. Hormones and Cancer. 2018;9(5):349-60.

32. Docherty JJ, Fu MM, Hah JM, Sweet TJ, Faith SA, Booth T. Effect of resveratrol on herpes simplex virus vaginal infection in the mouse. Antiviral Res. 2005;67(3):155-62.

33. Jung HJ, Seu YB, Lee DG. Candicidal action of resveratrol isolated from grapes on human pathogenic yeast C albicans. Journal of microbiology and biotechnology. 2007;17(8):1324-9.

34. Costa C, Lodesani M, Maistrello L. Effect of thymol and resveratrol administered with candy or syrup on the development of Nosema ceranae and on the longevity of honeybees (Apis mellifera L.) in laboratory conditions. Apidologie. 2010;41(2):141-50.

35. Giri BR, Bharti RR, Roy B. In vivo anthelmintic activity of Carex baccans and its active principle resveratrol against Hymenolepis diminuta. Parasitology reseaarch. 2015;114(2):785-8.

36. Moon $\mathrm{H}$, Sim J. Antimalarial activity in mice of resveratrol derivative from Pleuropterus ciliinervis. Ann Trop Med Parasitol. 2008;102(5):447-50.

37. Passos CLA, Ferreira C, Soares DC, Saraiva EM. Leishmanicidal effect of synthetic trans-resveratrol analogs. PLoS One. 2015;10(10):e0141778.

38. Dörrie J, Gerauer H, Wachter Y, Zunino SJ. Resveratrol induces extensive apoptosis by depolarizing mitochondrial membranes and activating caspase-9 in acute lymphoblastic leukemia cells. Can Res. 2001;61(12):4731-9.

39. Cianciulli A, Calvello R, Cavallo P, Dragone T, Carofiglio V, Panaro MA. Modulation of NF-KB activation by resveratrol in LPS treated human intestinal cells results in downregulation of PGE2 production and COX-2 expression. Toxicol In Vitro. 2012;26(7):1122-8.

40. Qureshi AA, Guan XQ, Reis JC, Papasian CJ, Jabre S, Morrison DC, Qureshi N. Inhibition of nitric oxide and inflammatory cytokines in LPS-stimulated murine macrophages by resveratrol, a potent proteasome inhibitor. Lipids Health Dis. 2012;11(1):1-17.

\section{Publisher's Note}

Springer Nature remains neutral with regard to jurisdictional claims in published maps and institutional affiliations.

Ready to submit your research? Choose BMC and benefit from:

- fast, convenient online submission

- thorough peer review by experienced researchers in your field

- rapid publication on acceptance

- support for research data, including large and complex data types

- gold Open Access which fosters wider collaboration and increased citations

- maximum visibility for your research: over $100 \mathrm{M}$ website views per year

At BMC, research is always in progress.

Learn more biomedcentral.com/submissions 